\title{
Issues in Informing Science and Information Technology Volume 14, 2017
}

Edited by Eli B. Cohen

Informing Science Press 
Issues in Informing Science and Information Technology:

Volume 14, 2017

Editor: Eli B. Cohen, Informing Science Institute

Copyright (C) 2017 by the Informing Science Institute. All rights reserved.

(CC BY-NC 4.0) This article is licensed to you under a Creative Commons AttributionNonCommercial 4.0 International License. When you copy and redistribute this paper in full or in part, you need to provide proper attribution to it to ensure that others can later locate this work (and to ensure that others do not accuse you of plagiarism). You may (and we encourage you to) adapt, remix, transform, and build upon the material for any non-commercial purposes. This license does not permit you to use this material for commercial purposes.

Published by:

Informing Science Press

the publication arm of the

Informing Science Institute

131 Brookhill Court

Santa Rosa, California 95409 USA

Telephone: + 1.707.324-3171

Email: Publisher@InformingScience.org

Website: http://InformingSciencePress.com

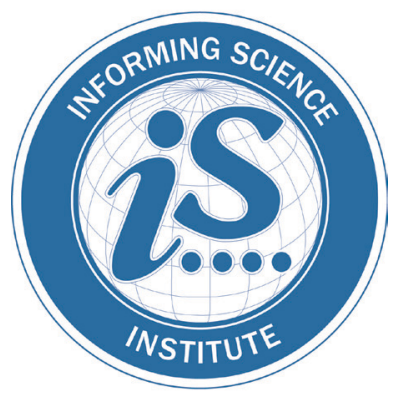

ISBN: 978-1-68110-025-8

ISSN: 1547-9684

Printed in the USA 


\section{The Journal of \\ Issues in Informing Science and Information Technology}

\section{Volume 14, 2017}

\section{Table of Contents}

Executive Higher Education Doctoral Programs in the United States: A Demographic MarketBased Analysis

Gracie Forthun and Sydney Freeman, Jr.

Can Learners Become Teachers? Evaluating the Merits of Student Generated Content and Peer Assessment

David Murray, Tanya McGill, Nik Thompson, and Danny Toohey

The Impact of a University Experience Program on Rural and Regional Secondary School Students: Keeping the Flame Burning

Joy Penman and Jyothi Thalluri

Hybrid App Approach: Could It Mark the End of Native App Domination?

Minh Huynh, Prashant Ghimire, and Donny Truong

The Workforce for the 21st Century

Henry O'Lawrence

Ransomware: A Research and a Personal Case Study of Dealing with this Nasty Malware

Azad Ali

The Elements Way: Empowering Parents, Educators, and Mentors in the Age of New Media

Gila Cohen Zilka 101-119

Assessing the Affordances of SimReal+ and Their Applicability to Support the Learning of Mathematics in Teacher Education

Said Hadjerrouit 121-138

Innovating and Entrepreneurial Initiatives: Some Cases of Success

Marta Machín-Martínez and Carmen de-Pablos-Heredero

Collaboration in Multi-stakeholder, Multi-cultural Organizational Environments

Douglas A. Straka 163-175

The Use of Kanban to Alleviate Collaboration and Communication Challenges of Global Software Development

Maureen Tanner and Marcelo Dauane

Representations of Practice - Distributed Sensemaking Using Boundary Objects Inge Hermanrud, Dorthe Eide

Entertaining Whilst Defacing Websites: Psychological Games for Hackers

Ashish K Das, Quynh T Nguyen, Susan Thomas 


\section{Review Process}

Except where otherwise noted, all papers were reviewed blindly (that is, with author and affiliation information removed) by between 6 and 10 external reviewers. The reviewers did not know the identity of the authors nor the authors of the reviewers. Reviewers were matched to papers using a formula to minimize the psychological distance between reviewers' stated expertise and interest and the topics covered in the paper. In cases where this formula did not provide at least 6 reviewers, reviewers were randomly assigned to papers. No reviewer was required to review more than 3 papers.

Reviewers were instructed to mentor the authors by providing feedback on how to improve the submission. They were further required to recommend whether or not the paper should be accepted using a six-point scale (from "reject" to "must accept").

The authors of all papers, whether accepted or not, were provided with the reviewers' feedback, as part of our process of mentoring authors. Authors of accepted papers were required to revise their submissions in light of the issues raised in the reviews.

We believe that the papers in this journal represent a great contribution to science. 